\title{
Effect of Halide Ions on the Adsorption Prewave of Methylene Blue
}

\author{
By \\ Kiyoshi Hasebe and Tomihito Kambara \\ (Department of Chemistry, Faculty of Science, Hokkaido University, Sapporo-shi, Japan, 060)
}

(Received August 29, 1973)

\section{Synopsis}

In the present study, the familiar Langmuir adsorption isotherm is applied to the mixed adsorption of methylene blue in the presence of halide ion. The variation of methylene blue prewave height or AC peak height with halide ion concentration is treated statistically. It is concluded that the decrease in the DG prewave or in the corresponding AG peak height is caused by the mixed adsorption of halide ion. The relative temperature coefficient of $\mathrm{AC}$ perk height was found to be $1.04 \% \mathrm{deg}^{-1}$ at $25^{\circ} \mathrm{C}$ in $0.4 M \mathrm{KNO}_{3}$ with acetate buffer solution ( $\mathrm{pH} 4.7$ ).

\section{Introduction}

The electrode process of methylene blue on a dropping mercury electrode was first clarified by Brdicka ${ }^{1)}$. It was concluded that the process is the reduction-oxidation reaction with adsorption phenomenon. Electroactive substances, such as the leucoform of methylene blue and diethyldithiocarbamate, give a high sensitivity in electroanalytical determination, especially, in $\mathrm{AC}$ or high-frequency polarography ${ }^{2-4)}$. The adsorption prewave and also the corresponding AC peak height of methylene blue is affected by chloride and bromide ions ${ }^{5)}$; iodide ion reduces methylene blue to the colorless leucoform.

\section{Theory of Mixed Adsorption of Methylene Blue and Halide Ion.}

If the halide ion, $X^{-}$, is mixed-adsorbable with methylene blue on the mercury electrode surface, Langmuir adsorption isotherm might be applied as follows.

$$
a_{M B}=\frac{Z \omega_{M B}[\mathrm{MB}]}{1+\omega_{M B}[\mathrm{MB}]+\omega_{X}\left[X^{-}\right]}
$$

In this equation, $a_{M B}$ is the number of moles of methylene blue leucoform adsorbed on $1 \mathrm{~cm}^{2}$ of the electrode surface, $\mathrm{Z}$ represents the maximum number of moles adsorbable per unit area of surface, $\omega$ is the adsorption coefficient, [ ] is the equilibrium concentration at the electrode surface, and the suffices $\mathrm{MB}$ and $X^{-}$refer to methylene blue and halide ion, respectively.

If the adsorption equilibrium is attained quickly, as soon as the new drop surface is formed, and if $a_{M B}$ is directly proportional to the DC polarographic prewave height, as first proposed by Brdicka, and further to the AC peak height of methylene blue, it may be expected that between the halide ion concentration and the reciprocal of $i_{D C}$ a linear relationship should hold; i.e.

$$
\frac{1}{i_{D C}}=\frac{a\left[X^{-}\right]}{C_{M B}}+b
$$


Analogously, one has for the AG peak height $i_{A C}$

$$
\frac{1}{i_{A C}}=\frac{a^{\prime}\left[X^{-}\right]}{C_{M B}}+b
$$

where $a, b, a^{\prime}$ and $b^{\prime}$ are constants.

\section{Experimental}

Apparatus A Yanagimoto polarograph, type PA-102, was used. In AC polarographic measurement, the cell was a modified Kalousek cell with a separated saturated calomel electrode as the reference, which was connected to the electrolysis cell by an agar bridge with saturated $\mathrm{KNO}_{3}$. The cell was short-circuited between mercury pool and the SCE by a $1000-\mu \mathrm{F}$ condenser. The electrolysis solutions were degassed with pre-purified nitrogen gas during the measurement. The temperature of the cell, except in the study of temperature dependence, was thermostatted to $25 \pm 0.1^{\circ} \mathrm{C}$. The $\mathrm{pH}$ value of the solution was measured with a glass electrode $\mathrm{pH}$ meter (Hitachi-Horiba, model F-5). The dropping mercury electrode used had the mercury flow rate of 1.15 $\mathrm{mg} \mathrm{sec} \mathrm{se}^{-1}$ and the drop time of $6.48 \mathrm{sec}$ at the mercury pressure, $h=80 \mathrm{~cm}$. These values were measured in an air-free water at the open-circuit.

Reagents $10^{-3} M$ methylene blue standard solution was prepared from a Merck AG product for microscopy. According to Wopschall and Shain ${ }^{6)}$, the methylene blue specimen was considered to contain two hydration waters. All the other chemicals used were of an analytical reagent grade. Water used was first put through a deionizer, and then distilled. Maximum suppressor was not employed. Buffer solutions were prepared according to the Walpole's system, $0.2 M \mathrm{CH}_{3} \mathrm{COOH}-0.2 M \mathrm{CH}_{3} \mathrm{COONa}$. The electrolysis solution usually contained $10 \mathrm{ml}$ of the above buffer solution in the total volume of $25 \mathrm{ml}$.

\section{Results and Discussion}

$D C$ and $A C$ polarograms of methylene blue and regression analysis.

In the DC polarography, only a single reduction prewave is observed with the concentration lower than the critical concentration of $5 \times 10^{-5} M^{5)}$, and the main wave does not appear. Figures 1 and 2 illustrate the DG and AG polarograms with the supporting electrolyte, that is, $0.4 M$ in potassium nitrate containing acetate buffer $(\mathrm{pH} 4.7$ ), to which various amounts of potassium bromide are added. Further, it was found that methylene blue peak is also slightly suppressed by the addition of chloride ion. The chloride ion in concentrations higher than $1 \times 10^{-2} M$ interferes with methylene blue peak remarkably. The AG polarographic peak is distinctly prominent as is shown in Fig. 2. With the increasing halide ion concentration, however, the half-wave potential of anodic halide wave is shifted to the more positive potential and finally overlaps the methylene blue wave.

The regression analysis is applied to the equations, (2) and (3), and the regression coefficient, $r$, is evaluated. The result is summarized in Tables I-III, and shown in Figs. 3-5.

According to equation (3), the slope of straight line in Fig. 5 should be inversely proportional to the methylene blue concentration. The slope values estimated statistically are given in Table III and the slope ratio is shown in Table IV. A fairly good 


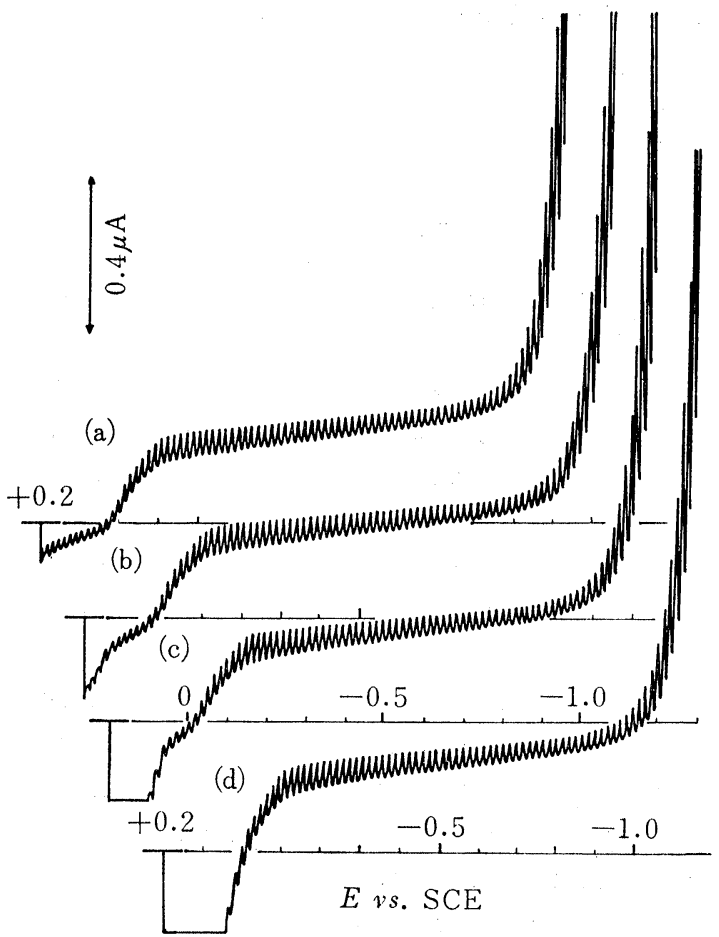

Fig. 1. DG polarographic adsorption prewave of $5 \times 10^{-5} M$ methylene blue in $0.4 M \mathrm{KNO}_{3}+$ acetate buffer $(\mathrm{pH} 4.7)$ containing $\mathrm{KBr}$.

The $\mathrm{KBr}$ concentration is (a) $1 \times 10^{-5} \mathrm{M}$, (b) $5 \times 10^{-5} \mathrm{M}$, (c) $1 \times 10^{-4} \mathrm{M}$, (d) $1 \times 10^{-3} M$.

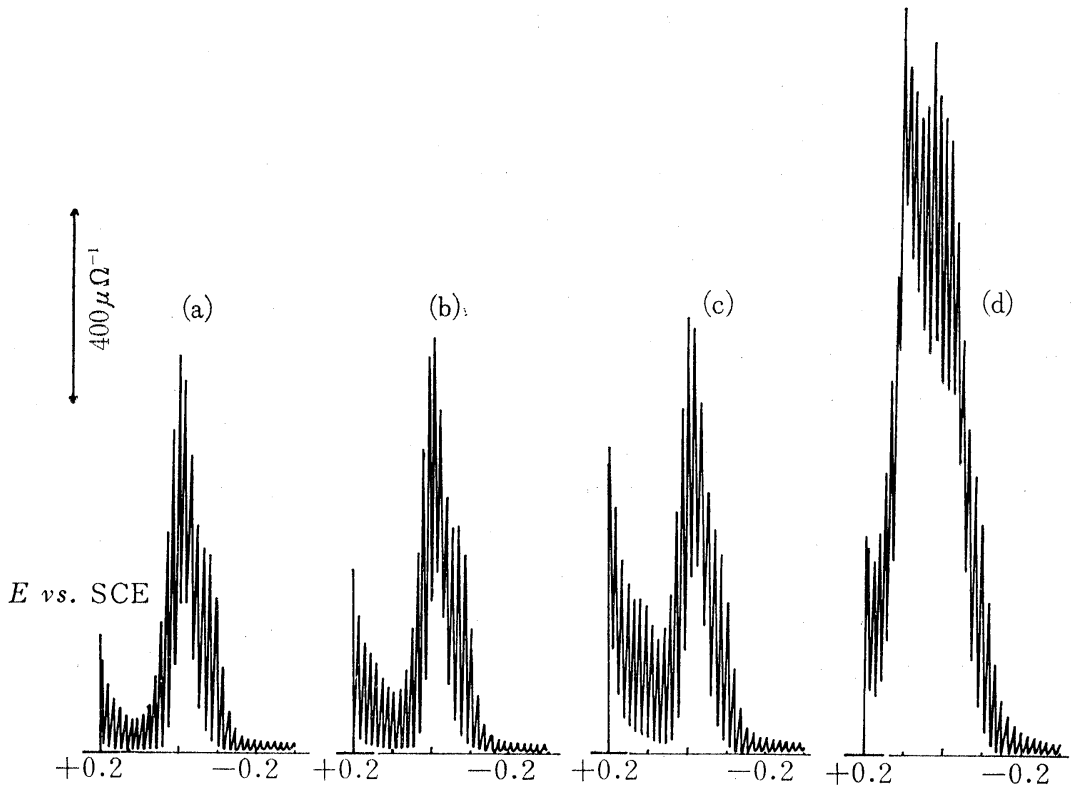

Fig. 2 AG polarographic wave of methylene blue corresponding to Fig. 1. 


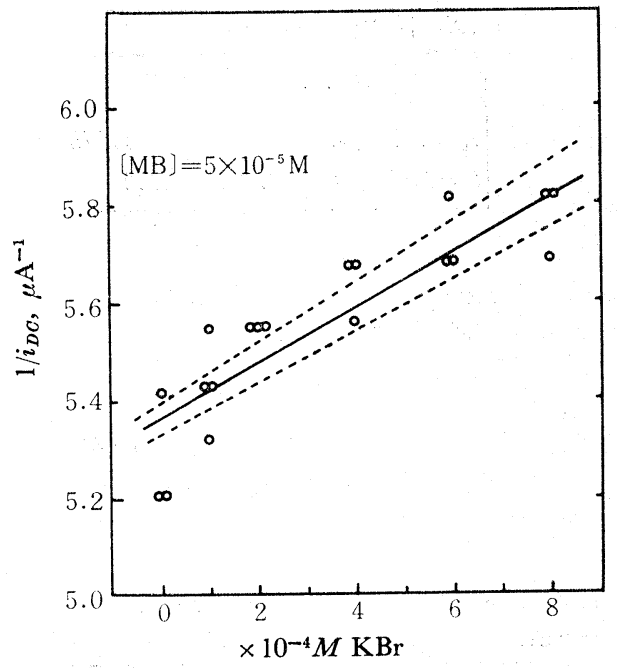

Fig. 3. The relationship between the reciprocal of the DG wave height and the concentration of bromide ion added. The supporting electrolyte is the same as in Fig. 1.

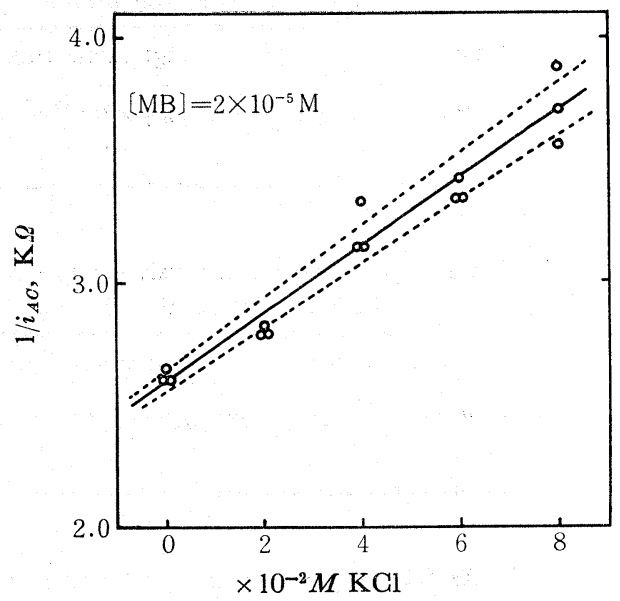

Fig. 4. The relationship between the reciprocal of the AC peak height and the concentration of chloride ion added. The supporting electrolyte is $0.4 M \mathrm{KNO}_{3}+$ acetate buffer ( $\mathrm{pH} 4.7$ ).

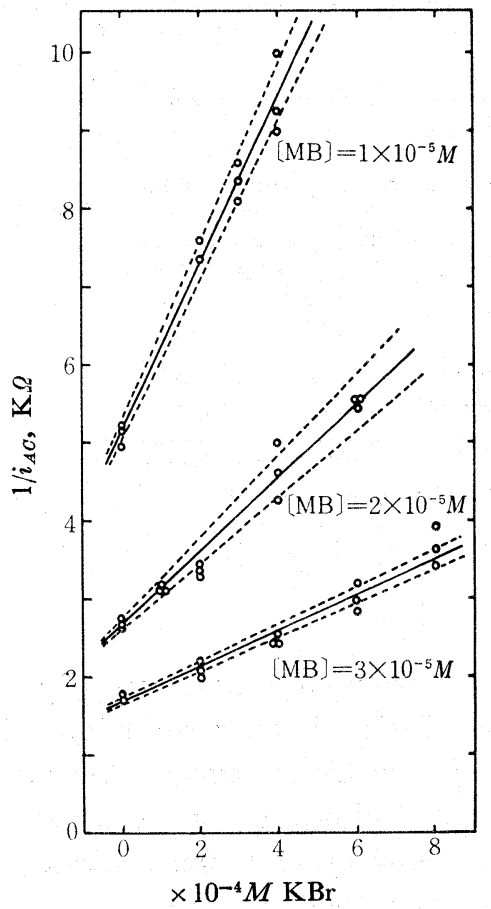

Fig. 5. The relationship between the reciprocal of the $\mathrm{AC}$ peak height and the concentration of bromide ion added. The supporting electrolyte is the same as in Fig. 1. 
Table I. Regression analysis for the reciprocal of methylene blue wave height $\left(Y=1 / i_{D C}\right)$ and the bromide concentration $\left(X=\left|\mathrm{Br}^{-}\right|\right)$. (cf. Fig. 3)

\begin{tabular}{c|c|c}
\hline MB concn. & Regression line & \multicolumn{1}{|c}{ Result of $t$-test } \\
\hline $5 \times 10^{-5} M$ & $Y=(5.66 \pm 0.500) \times 10^{2} X+(5.34 \pm 0.022)$ & $\begin{array}{l}r_{0}=0.876>r(19-2,0.01)=0.575 \\
t_{0}=7.493>t(17,0.01)=2.90\end{array}$ \\
\hline
\end{tabular}

Table II. Regression analysis for the reciprocal of methylene blue peak height $\left(Y=1 / i_{A C}\right)$ and the chloride concentration $\left(X=\left|\mathrm{Cl}^{-}\right|\right)$. (cf. Fig. 4).

\begin{tabular}{c|c|c}
\hline MB concn. & Regression line & \multicolumn{1}{|c}{ Result of $t$-test } \\
\hline $2 \times 10^{-5} M$ & $Y=(13.73 \pm 0.77) \times X+(2.59 \pm 0.04)$ & $\begin{array}{l}r_{0}=0.973>r(15-2,0.01)=0.641 \\
t_{0}=15.25>t(13,0.01)=3.01\end{array}$ \\
\hline
\end{tabular}

Table III. Regression analysis for the reciprocal of methylene blue peak height $\left(Y=1 / i_{A C}\right)$ and the bromide concentration $\left(X=\left|\mathrm{Br}^{-}\right|\right)$. (cf. Fig. 5).

\begin{tabular}{c|c|l}
\hline MB concn. & \multicolumn{1}{|c|}{ Regression line } & \multicolumn{1}{|c}{ Result of $t$-test } \\
\hline $1 \times 10^{-5} M$ & $Y=(1.08 \pm 0.05) \times 10^{4} X+(5.14 \pm 0.14)$ & $\begin{array}{l}r_{0}=0.985>r(12-2,0.01)=0.708 \\
t_{0}=3.195>t(10,0.01)=3.169 \\
r_{0}=0.984>r(15-2,0.01)=0.641 \\
t_{0}=20.8>t(13,0.01)=3.01\end{array}$ \\
$3 \times 10^{-5} M$ & $Y=(4.85 \pm 0.467) \times 10^{3} X+(2.59 \pm 0.016)$ & $\begin{array}{l}r_{0}=0.972>r(25,0.01)=0.487> \\
r(26,0.01) \\
t_{0}=20.91>t(24,0.01)=2.80\end{array}$ \\
\hline
\end{tabular}

Table IV. The slope ratio of the regression lines shown in Fig. 5.

\begin{tabular}{c|c|c|c}
\hline $\begin{array}{c}\text { Concentration of } \\
\mathrm{MB}, M\end{array}$ & $\begin{array}{c}\text { Slope of regression } \\
\text { line }\end{array}$ & $\begin{array}{c}\text { Relative ratio of } \\
\text { slope (found) }\end{array}$ & $\begin{array}{c}\text { Reciprocal of the MB concn. ratio } \\
\text { (theoretical slope ratio), } \times 10^{5}\end{array}$ \\
\hline $1 \times 10^{-5}$ & $1.08 \times 10^{4}$ & 1.00 & 1.00 \\
$2 \times 10^{-5}$ & $4.85 \times 10^{3}$ & 0.451 & 0.50 \\
$3 \times 10^{-5}$ & $2.28 \times 10^{3}$ & 0.212 & 0.33 \\
\hline
\end{tabular}

The denominator is the slope of $1 \times 10^{-5} M$ methylene blue, and the numerators, the slopes of $3 \times 10^{-5} M, 2 \times 10^{-5} M$ and $1 \times 10^{-5} M$, respectively.

accordance is found.

\section{Electrocapillary curve}

As is well known, the electrocapillary curve can offer some important information as to adsorption phenomena. Figure 6 shows the relationship between the drop time and the potential of dropping mercury electrode. Methylene blue clearly lowers the interfacial tension as the result of adsorption of the reduced form at the mercury surface. Furthermore, with increasing bromide ion concentration, the interfacial tension is lowered at the potential of methylene blue prewave. Namely, the bromide ion is evidently adsorbed onto the dropping mercury electrode with methylene blue. Such a phenomenon is also observable in the electrocapillary curve of methylene blue solution to which chloride ion is added. This fact indicates most strongly the evidence for the mixed adsorption of methylene blue and halide ion. 


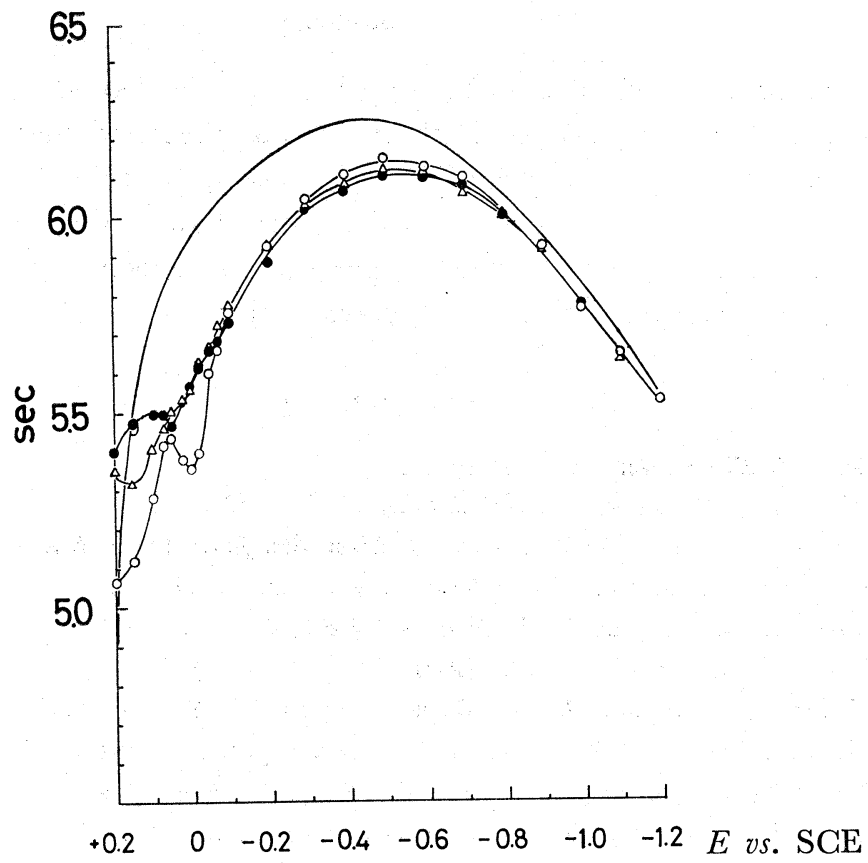

Fig. 6. The electrocapillary curves of $5 \times 10^{-5} M$ methylene blue in the supporting electrolyte as stated in Fig. 1.

The full line : without $\mathrm{KBr} ; \bigcirc: 1 \times 10^{-3} M \mathrm{KBr} ; 0: 1 \times 10^{-4} M \mathrm{KBr}$; $\triangle: 1 \times 10^{-5} M \mathrm{KBr}$.

The temperature dependence of $A C$ polarographic peak height of methylene blue in various electrolyte solutions

According to several authors ${ }^{1,7,8)}$, adsorption current shows various temperature dependences, for example, as summarized by Zuman ${ }^{9)}$. With several kinds of supporting electrolyte, the temperature dependences of $\mathrm{AC}$ peak height are measured, as summarized in Table $\mathrm{V}$.

Table V. The relative temperature coefficient of $2 \times 10^{-5} M$ methylene blue AG peak height at $25^{\circ} \mathrm{G}$ in various supporting electrolyte solutions.

\begin{tabular}{l|c|c}
\hline \multicolumn{1}{c|}{ Supporting electrolyte } & $\begin{array}{c}\text { Temperature } \\
\text { range, }{ }^{\circ} \mathrm{C}\end{array}$ & $\begin{array}{c}\text { Relative temperature } \\
\text { coefficient }\end{array}$ \\
\hline $0.4 M \mathrm{NH}_{4} \mathrm{OH}-0.4 M \mathrm{NH}_{4} \mathrm{NO}_{3}$ & $2-45$ & $1.61 \% \mathrm{deg}^{-1}$ \\
$* 0.08 M \mathrm{Na}_{2} \mathrm{G}_{2} \mathrm{O}_{4}-0.16 M \mathrm{H}_{2} \mathrm{C}_{2} \mathrm{O}_{4}$ & $5-15$ & $0 \% \mathrm{deg}^{-1}$ \\
$0.4 M \mathrm{H}_{2} \mathrm{SO}_{4}$ & $15-52$ & $-1.10 \% \mathrm{deg}^{-1}$ \\
$0.4 M \mathrm{KNO}_{3}+$ Acetate buffer & $1-50$ & $-1.35 \% \mathrm{deg}^{-1}$ \\
$(\mathrm{pH} 4.7)$ & $2-50$ & $1.04 \% \mathrm{deg}^{-1}$ \\
\hline
\end{tabular}

Measurements were carried out versus mercury pool.

The sufficient conductivity of the electrolysis solution was confirmed by the variation of electrode distance.

* If the temperature becomes below $5^{\circ} \mathrm{C}$, precipitation occurs. 


\section{Summary}

The mixed adsorption of methylene blue and halied ion was investigated. On the basis of Langmuir adsorption isotherm, it was predicted that an linear relationship exists between the reciprocal of the DG wave height, or of the $A C$ peak height, and the halide ion concentration. Experimental results showed the essential validity of the theoretical prediction. Finally, the temperature dependences of methylene blue peak height had been studied by the AC polarography.

\section{References}

1) R. Brdicka, Z. Elektrochem., 48, 278 (1942).

2) T. Kambara and K. Hasebe, Bunseki Kagaku, 14, 491 (1965).

3) T. Kambara, S. Tanaka and K. Hasebe, J. Chem. Soc. Japan (Pure chem. sect.), 88, 644 (1967).

4) K. Hasebe and T. Kambara, Rev. Polarog. (Kyoto), 15, 37 (1968).

5) K. Hasebe and T. Kambara, Bull. Chem. Soc. Japan, 43, 2110 (1970).

6) R. H. Wopschall and I. Shain, Anal. Chem., 39, 1527 (1967).

7) I. Tachi and T. Tsukamoto, J. Agri. Chem. Soc. Japan, 25, 436, 442 (1952).

8) M. Senda, S. Shibabe and E. Okada, Rev. Polarog. (Kyoto), 14, 392 (1967).

9) P. Zuman, "Organic Polarographic Analysis", Pergamon Press, New York, p. 25 (1964) ; translated in Japanese (Kyoritsu Shuppan) by S. Ono and M. Takagi (1967).

\section{メチレンブルーの吸着前置波におよぼすハロゲン化物イオンの影響}

\section{長谷部 清，神原 富民} (北海道大学理学部化学科 060 札幌市北区北 10 西 8 )

\footnotetext{
ハロゲン化物イオンの存在のもとでメチレンブルー の混合吸着にラングミュア吸着等温式を適用した。 メ チレンブルー吸着前置波高，あるいは交流ピーク波高 とハロゲン化物イオン濃度との間の変動を統計学的に 取扱かった．直流前置波高の減少，あるいは対応する 交流ピーク波高のそれは，ハロゲン化物イオンの混合
}

吸着によって引き起てされると結論される。また，こ のととは電気毛管曲線の結果から明らかである.さ らに,メチレンブルーの交流ピークの温度依存性が, 種々の支持電解質中で検討され，酢酸緩衝溶液を含む $0.4 M$ 硝酸カリウム中では, $25^{\circ} \mathrm{C}$ 亿扔ける相対温度係 数は $1.04 \% \mathrm{deg}^{-1}$ であった。 